\title{
ANALISIS FAKTOR RISIKO WASTING PADA BALITA DI WILAYAH KERJA PUSKESMAS IDI RAYEUK KABUPATEN ACEH TIMUR TAHUN 2019
}

\author{
Anna Dara Tambunan ${ }^{1}$ \\ Pasca Sarjana Institut Kesehatan Helvetia, Medan, Indonesia \\ annadara@yahoo.com
}

\begin{abstract}
The purpose of this study was to analyze the risk factors for wasting in infants in the Idi Rayeuk Health Center District of East Aceh in 2019. This study was an analytical study with case control design (case control design) with a total of 86 respondents. Collection data is done using questionnaires, while data analysis is on this study uses multivariate multiple logistic regression data analyzed by univariate, bivariate with chi square test and multivariate with logistic regression test. The results of statistical tests showed that odds ratios (OR) of infectious diseases were 15,797, meaning that children under five with a history of infectious diseases had a 15.7 times chance of being wasted compared to children with no history of infectious diseases. It is expected that health workers, especially the implementation of nutrition programs to be able to monitor regularly and overcome the problem of nutritional status of infants, especially wasting problems experienced by toddlers.
\end{abstract}

Abstrak:Tujuan penelitian ini adalah untuk menganalisis faktor risiko wasting pada balita di Wilayah Kerja Puskesmas Idi Rayeuk Kabupaten Aceh Timur Tahun 2019. Penelitian ini merupakan penelitian analitik dengan desain kasus control (case control design) dengan jumlah responden sebanyak 86 responden. Pengumpulan data yang dilakukan dengan menggunakan kuisioner, sedangkan analisa data pada penelitian ini menggunakan analisa multivariat Regresi Logistik Berganda Data dianalisis secara univariat, bivariat dengan uji chi square dan multivariate dengan uji regresi logistik. Hasil uji statistika diperoleh didapatkan odds ratio (OR) penyakit infeksi sebesar 15,797 artinya balita yang mengalami riwayat penyakit infeksi memiliki peluang 15,7 kali mengalami wasting dibandingkan balita yang tidak memiliki riwayat penyakit infeksi. Diharapkan kepada petugas kesehatan khususnya pelaksanaan program gizi agar dapat memantau secara berkala dan mengatasi masalah status gizi balita terutama masalah wasting yang dialami balita.

Kata Kunci : Wasting,Balita.

Corresponding Author :

Anna dara tambunan

JIn. STM Suka Cita No. 4 Medan

Email : annadara@yahoo.com
Copyright (C) 2019 Jurnal Skala Kesehatan. Politeknik Kesehatan Banjarmasin All rights reserved

Vol 10 No. 2 Juli 2019 


\section{PENDAHULUAN}

Gangguan gizi yang terjadi pada balita mempengaruhi pertumbuhan dan perkembangan, baik pada masa balita maupun masa berikutnya sehingga perlu mendapatkan perhatian dan penanggulangan gizi kurang memerlukan upaya yang menyeluruh (1). Pengaruh kekurangan gizi tidak hanya berpengaruh terhadap perkembangan fisik tetapi juga terhadap perkembangan kognitif yang pada gilirannya berpengaruh terhadap kecerdasan dan ketangkasan berpikir serta terhadap produktifitas kerja, kekurangan gizi pada masa ini juga dikaitkan dengan resiko terjadinya penyakit kronis pada usia dewasa, yaitu kegemukan, penyakit jantung dan pembuluh darah, hipertensi, stroke dan diabetes (2).

Balita yang mengalami wasting atau kurus disebabkan karena kejadian tersebut baru terjadi atau akut yaitu penurunan asupan gizi yang drastis atau menderita penyakit sehingga berat badannya berkurang, balita seperti ini disebut mengalami masalah gizi akut Berdasarkan pemantauan status gizi (PSG) Tahun 2013 di Indonesia terdapat sebanyak $2,8 \%$ balita mempunyai status gizi sangat kurus dan $6,7 \%$ balita mempunyai status gizi kurus (3). Berdasarkan hasil Survai Pemantauan Status Gizi Provinsi Aceh Tahun 2015 didapatkan masalah status gizi balita kurus atau wasting di Aceh Timur pada tahun 2017 sebesar 11,2\% (4).

Menurut Merryana (2016) Status gizi dapat dipengaruhi oleh faktor langsung dan tidak langsung. Faktor langsung yang menimbulkan masalah gizi ialah kurangnya asupan makan dan penyakit infeksi. Kekurangan asupan makan disebabkan karena tidak tersedianya pangan pada tingkat rumah tangga sehingga tidak ada makanan yang dapat dikomsumsi. Kekurangan asupan makanan juga disebabkan oleh perilaku atau pola asuh orang tua yang kurang baik pada anak seperti orang tua lebih mementingkan memakai perhiasan dibandingkan untuk menyediakan makanan bergizi. Faktor tidak langsung mencakup jumlah anggota keluarga, pekerjaan, tingkat pendapatan keluarga, pemberian ASI Ekslusif (5).

Penyakit infeksi dapat memperburuk keadaan gizi sehingga mudah terserang infeksi. Infeksi yang berlanjut akan menghambat pertumbuhan fisik anak sehingga anak menderita wasting. Hasil penelitian Afriyani (2016) menunjukkan faktor dominan terjadinya wasting pada balita adalah penyakit infeksi, balita yang sering menderita penyakit infeksi berisiko 3,512 kali mengalami wasting dibandingkan anak yang tidak menderita penyakit infeksi (6).

Rendahnya pemberian ASI merupakan ancaman ancaman bagi tumbuh kembang anak yang berpengaruh pada pertumbuhan dan perkembangan kualitas sumber daya manusia secara umum. Penelitian Lestari (2016) menunjukkan bahwa anak yang tidak mendapatkan ASI Ekslusif memiliki risiko 3,025 kali mengalami wasting dibandingkan anak yang tidak mendapatkan ASI Ekslusif (7). 


\section{METODE}

Metode penelitian yang dipergunakan dalam penelitian ini adalah penelitian analitik dengan desain kasus control (case control design). Penelitian ini dilakukan di Wilayah Kerja Puskesmas Idi Rayeuk Kabupaten Aceh Timur. Penelitian ini dilakukan pada bulan Januari s/d Maret 2019. Adapun populasi dalam penelitian ini sebanyak 86 responden. Pengumpulan data didapatkan dari berpedoman dengan kuesioner. Analisa data yang telah dilakukan menggunakan analisa Multivariat dengan Uji Statistika Regresi Logistik Berganda.

\section{HASIL DAN PEMBAHASAN}

Hasil seleksi bivariat, variabel yang menghasilkan $p$ value $<0,25$ yaitu : Penyakit infeksi, riwayat ASI Ekslusif, pendapatan keluarga, pola asuh, riwayat imunisasi dasar. dimasukkan dalam pemodelan multivariate.

Tabel 1. Hasil Seleksi Bivariat sebagai Kandidat (pemodelan) Multivariat

\begin{tabular}{clc}
\hline No. & Variabel & p value (sig) \\
\hline 1. & Penyakit Infeksi & 0,000 \\
2. & Riwayat ASI Ekslusif & 0,018 \\
3. & Pendapatan Keluarga & 0,049 \\
4. & Pola Asuh & 0,010 \\
5. & Riwayat Imunisasi Dasar & 0,025
\end{tabular}

Tabel 2. Model Akhir Multivariat faktor risiko wasting pada balita di Wilayah Kerja Puskesmas Idi Rayeuk Kabupaten Aceh Timur

\begin{tabular}{lllcc}
\hline \multicolumn{1}{c}{ Variabel } & B & Sig. & $\begin{array}{c}\text { Exp(B) } \\
(\mathbf{O R})\end{array}$ & 95\%Cl for $\operatorname{Exp(B)}$ \\
\hline Penyakit Infeksi & $\mathbf{2 . 7 6 0}$ & $\mathbf{0 , 0 0 0}$ & $\mathbf{1 5 , 7 9 7}$ & $\mathbf{3 , 8 0 2 - 6 5 , 6 3 2}$ \\
Riwayat ASI Ekslusif & 1.950 & 0,004 & 7,026 & $1,864-26,485$ \\
Pendapatan Keluarga & 1,570 & 0,021 & 4,807 & $1,261-18,324$ \\
Pola Asuh & 2,532 & 0,001 & 12,574 & $2,957-53,473$ \\
Riwayat Imunisasi Dasar & 1,427 & 0,040 & 4,166 & $1,065-16,289$
\end{tabular}

Dari analisis multivariat ternyata variabel faktor risiko yang paling dominan terhadap kejadian wasting pada balita adalah Variabel yang paling dominan memiliki pengaruh signifikan terhadap wasting pada balita adalah penyakit infeksi dengan nilai 
odds ratio (OR) adalah 15,797 artinya balita yang mengalami penyakit infeksi memiliki peluang 15,7 kali mengalami wasting dibandingkan yang tidak mengalami penyakit infeksi. Hasil penelitian ini sejalan dengan Afriyani (2016) diperoleh nilai odds ratio (OR) adalah 3,512 artinya penyakit infeksi merupakan faktor risiko dari kejadian wasting dan balita yang mengalami penyakit infeksi berisiko 3,5 kali mengalami kejadian wasting dibandingkan dengan balita yang tidak mengalami penyakit infeksi (6).

Menurut Victora et al. (1999) menyatakan bahwa kurang gizi pada anak menurunkan sistem imun yang akhirnya akan meningkatkan risiko terjadinya penyakit infeksi. Keadaan kurang gizi mempunyai efek terhadap mekanisme pertahanan terhadap antigen, serta berpengaruh juga terhadap respon imun yang lebih khusus (8). Penurunan respon seperti itulah yang menyebabkan virus dengan mudah menginfeksi dan bereplikasi, sehingga timbullah penyakit infeksi pada anak tersebut. Kaitan penyakit infeksi dengan keadaan gizi kurang merupakan hubungan timbal balik, yaitu hubungan sebab akibat. Penyakit infeksi dapat memperburuk keadaan gizi, dan keadaan gizi yang jelek dapat mempermudah terkena infeksi (9).

Balita yang mengalami wasting dapat meningkatkan risiko kesakitan dan kematian anak. Anak yang wasting sangat mudah terkena penyakit infeksi. Apabila keadaan kurang gizi pada masa balita terus berlanjut, maka dapat mempengaruhi intellectual performance, kapasitas kerja, dan kondisi kesehatannya di usia selanjutnya.

Berdasarkan penelitian yang dilakukan Hendrayati (2013) penyakit infeksi seperti diare dan Infeksi Saluran Pernafasan Atas (ISPA) yang disebabkan oleh sanitasi pangan dan lingkungan yang buruk, berhubungan dengan kejadian wasting (10). Penelitian yang dilakukan Khan et al. (2016) juga menyatakan ada hubungan yang signifikan antara penyakit infeksi dengan kejadian wasting. Diare yang terjadi pada anak sangat berbahaya karena dapat menyebabkan tubuh kehilangan cairan dalam jumlah banyak. Diare sangat berhubungan dengan kerusakan yang terjadi pada mukosa usus sehingga protein, cairan dan zat lainnya tidak dapat terserap dengan baik. Selain itu terjadi masalah dalam aliran usus dan enzim pancreas. Seseorang dengan penyakit saluran pernafasan juga mengalami masalah yang dapat mempengaruhi asupan gizi (11). Penyakit Infeksi bisa berhubungan dengan gangguan gizi melalui beberapa cara, yaitu mempengaruhi nafsu makan, menyebabkan kehilangan bahan makanan karena diare dan mempengaruhi metabolisme makanan (12)

\section{KESIMPULAN}

Hasil analisis Regresi Logistik Berganda di wilayah kerja Puskesmas Idi Rayeuk Kabupaten Aceh Timur dengan jumlah responden sebanyak 86 orang didapatkan odds ratio (OR) variabel penyakit infeksi adalah 15,797 artinya balita yang mengalami penyakit infeksi memiliki peluang 15,7 kali mengalami wasting dibandingkan yang tidak mengalami penyakit infeksi. Variabel yang sangat dominan berisiko terjadinya wasting pada balita adalah variabel penyakit infeksi. 


\section{DAFTAR PUSTAKA}

1. Adriani M, Wirjatmadi B. Gizi dan kesehatan balita. Kencana Prenadamedia Gr. 2014;

2. Kementerian Kesehatan RI. Buku Panduan Germas. Jakarta; 2016.

3. Kesehatan K. Riset Kesehatan Dasar (Riskesdas). Kemenkes RI. 2013;

4. Kesehatan K. Rencana Strategis Kementerian Kesehatan'. Jakarta; 2015.

5. Ariesthi KD. Faktor risiko gizi kurang pada balita di Nusa Tenggara Timur. CHMK Heal J. 2019;3(1):13.

6. Afriyani R, Malahayati N, Hartati H. Faktor-faktor yang Mempengaruhi Kejadian Wasting pada Balita Usia 1-5 Tahun di Puskesmas Talang Betutu Kota Palembang. J Kesehat. 2016;7(1):66-72.

7. Lestari ND. Analisis determinan gizi kurang pada balita di Kulon Progo, Yogyakarta. IJNP (Indonesian J Nurs Pract. 2016;1(1):15-21.

8. Hastoety SP, Wardhani NK, Sihadi S, Sari K, Putri DSK, Rachmalina R, et al. Disparitas Balita Kurang Gizi di Indonesia. Media Penelit dan Pengemb Kesehat. 2018;28(3):201-10.

9. Wahyono TYM, Putri DSK. Faktor Langsung dan Tidak Langsung yang Berhubungan dengan Kejadian Wasting pada Anak Umur 6-59 Bulan di Indonesia Tahun 2010. Media Penelit dan Pengemb Kesehat. 2013;23(3).

10. Hendrayati AA. Darmawati (2013). Faktor yang Mempengaruhi Kejadian Wasting pada Anak Balita di Kecamatan Marioriwawo Kabupaten Sopeng. Media Gizi Pangan, 15.

11. Hidayati L, Purwanto S, Zulaekah S. Gambaran Karakteristik Anak dan Karakteristik Keluarga Anak Malnutrisi di Wilayah Perkotaan Kota Surakarta. J Penelit Sains Teknol. 2017;13(1):11-20.

12. Asiah N, Prasetyo E, Birwin A. Kejadian stunting, wasting dan undeweight pada balita di Posyandu Wuring Tengah Wolomarang, Alok Barat, Kabupaten Sikka, NTT. In: Prosiding Kolokium Doktor dan Seminar Hasil Penelitian Hibah. 2018. p. 459-69. 